\title{
Land Policy for Sustainable Agricultural Land and its Implementation: Experiences from West Sumatra
}

\author{
Melinda Noer ${ }^{\#}$, Yossyafra ${ }^{*}$, Rini Hakimi ${ }^{\$}$, Muhamad Reza ${ }^{\$}$

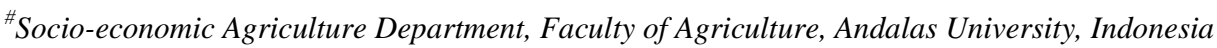 \\ E-mail: melindanoer@yahoo.com \\ *Civil Engineering Department, Faculty of Engineering, Andalas University, Indonesia \\ ${ }^{\$}$ Agricultural Sciences Study Program, Postgraduate Program, Andalas University, Indonesia
}

\begin{abstract}
Agriculture development in traditions requires land to grow the plant, either for consumption and industrial purposes. In one hand, it implies that land as resources is understood as an important and high value to attain sustainable agriculture development. In the other hand, land for agricultural use has realized lower value than land for commercial purposes. That results in land conversion from agriculture to non-agricultural land such as land for settlement and tends to happen increasingly at the alarming rate. However, food and settlement are considered as human basic needs. It dares to food supply which may not meet the demand. The main discussion is about how problematical of land competition for settlement and agriculture have been taking place in West Sumatra Province in Indonesia. So, how regulation on land use planning at the national level is being implemented at the provincial or sub-district/city level with regard to sustainable land for food and agriculture development. It is argued that land policy for agriculture and settlement development planning should be laid into an integrated and sustainable development planning thought and local regulation has to support.
\end{abstract}

Keywords — agriculture; settlement; land use; sustainable land

\section{INTRODUCTION}

Land for agricultural development needs a land policy to determine the suitability and number of land can be employed in the context of sustainability. The land is considered as an input of production which is important to attain agricultural development objectives, so that spatial or land use planning perspective should have been taken into account to achieve sustainable development. The urgency of this study is because of agricultural land conversion phenomenon have been increased and endangered within the last two decades.

The Indonesian government has mentioned in its regulation that every district or region in the country should have set land agricultural zone for food crop to guarantee the sustainable agricultural land and have to be written in both regional land use plan and regional development plan as well. The sustainable land for agriculture specifically for food has been in place for seven years, and there has not been evaluated formally yet. Indonesia government act concerning on sustainable agricultural land aims at maintaining self-sufficiency and food-security of the individual household [1].

However, land for agricultural purposes has been realized had a lower value than it for commercial purposes, which then impact on conversion of agricultural use to nonagricultural use which presently tends to increase. Demand for the land for housing and settlement are also growing because of the increasing number of population which lead to demanding on a place for living. Besides, a weak authorization system in housing development sector also contributes to uncontrolled land conversion in the last period.

Some publications stated that at least 150,000 hectares of rice field have been converted to nonfood agriculture land or settlement area, but there was no accuracy data defined where it took place. This happens because land use monitoring system and its statistics have not been developed yet, which is it also happens to West Sumatra. So, it is rarely discussed how land competition problematics of settlement and agriculture have been taking place in the case, and how evaluation on agricultural land regulation have been implemented with regard to the land use plan at provincial or district and municipality in Indonesia, including of West Sumatra.

In terms of sustainable development thought, land use plan in agriculture and settlement development must also be planned to reach a better condition through natural, economics, and social resources utilization. Interrelation analysis among any dimension of development will help to realize sustainability in development [2]. It is hoped that 
sustainability in agriculture and settlement development will fulfill the present needs without ignoring capability and opportunity of next generations to meet their equal needs in future. That is the reason why regional potential resources management needs to be integrated and synergetic planning in order to reach and maintain the sustainability of development objective.

The challenges of sustainable development are difficulties in resource capability especially land resources whereas land is become threatened to meet their increasing demand. Land resource gets an important part as the main issue in regional development planning and necessary to determine realization at local, regional, and national development objective.

It is argued that land policy for agriculture and settlement development planning should be laid into an integrated and sustainable development planning thought. An analysis of scientific literature on sustainability and food discovered that agriculture more connected to the environment [2], which then leads to sustainable development [3] in general and sustainable land for agriculture in specific.

\section{MATERIAL AND METHOD}

The objective of the research is to evaluate the implementation of land policy on food agriculture in West Sumatra Province. To get focus and detail of the study, Tanah Datar and Limapuluh Kota districts, and Padang and Pariaman municipalities in West Sumatra Province have been studied to attain the research objectives.

This research followed two steps, firstly is desk study on the land policies with regard to agricultural development and secondly is the land use mapping overlay. A desk study was conducted to inventory and investigate the related policy documents which support and enforce the implementation of sustainable agricultural land regulation at regional and district or municipality levels. Thus, land use mapping overlay was directed to evaluate the regional land use plan in which land is allocated for agriculture but has been used for housing and settlement area. Map of the land use plan in the year 2012 and Citra satellites map in the year 2015 was used for each study area and overlayed to run the second step.

Depth interviews were also conducted to get clear information and broad understanding upon implementation sustainable agricultural land regulation, where and why the gap of land use implementation occurred. Key informants for primary data which involved in this research came from the officials in Padang and Pariaman municipalities as well as Tanah Datar and Limapuluh Kota districts. Some of the informants were regulators and actors which dealing with the development activities or decision-making in public works, regional planning, food agricultural sector, statistics, and the body of regional land use the control at district and municipality have been studied. At the rural level (the lowest authority hierarchy), head of the village, which is locally named by Lurah and Walinagari, were also questioned to get more information about the role of village administrators in land conversion in the field. Key informants were selected by using snowball sampling method.

The research findings for desk study on regulations were analyzed using qualitative descriptive and interpretative analysis [4]. The conclusions of desk evaluation were made based on gap found between regulation that have been published to support sustainable agricultural land at the national level and what regulation have been implemented in regional (provincial / district) and the field of rural level within the study areas, using comparative study analysis. On the second step, quantitative descriptive analysis for land use mapping analysis was used to show where the use of land has been changed from agriculture purpose to settlement or housing. Data and confirmation from some key informants were used to enrich qualitative and quantitative descriptive analysis.

\section{RESULTS AND DISCUSSIONS}

\section{A. Description of the Study Areas}

Padang is a municipality of West Sumatra Province and is planned for a metropolitan city in 2025 as stated as a regional regulation in Long Term Development Plan of Kota Padang. Spatial plan of West Sumatra Province year 20122032 acknowledged that Padang is a national activity center and Pariaman is a regional activity center. Both municipalities are being planned to be metropolitan regions. However, according to Indonesian Act 41, 2009 every region has to delineate definite agricultural land for food and horticulture, including Padang and Pariaman municipalities.

In the district, according to Provincial land use plan No. 13, the year 2012, Tanah Datar and Limapuluh Kota districts have to delineate an agropolitan area with agricultural land for dry land of food and horticulture. In Tanah Datar rice field is located dominantly in Sungai Tarab sub-district, whereas in Limapuluh Kota it is located in Situjuh. Both districts established minapolitan and agropolitan areas. While Kota Padang dan Kota Pariaman are not demarcated for rice field because they are planned to be a metropolitan area.

Table 1 shows statistics about rice field and its growth in the study areas. Padang and Pariaman have decreased their land for rice field, but in the meantime, Tanah Datar and Limapuluh Kota experienced increasing rice field in the period of 2009 to 2014 [5].

\section{B. Needs for Policy on Protection of Sustainable Land for Food Agriculture in Indonesia: Desk Study Analysis}

Basic needs theory set food and housing are human basic needs as well as clothing. Those require land as resource and indicators of development as well in which need to perform at the same time but compete within their availability. Land in food agriculture tends to be less which then impact on decreasing in food production and also its productivity. The community and private business saw that the agricultural land has a lower economic value than non-agricultural (housing and settlement).

Agriculture development sector in Indonesia grew about $3.4 \%$ of Gross Domestic Product in average, whereas 2\% growth by food agriculture sub-sector. However, unskilled farmers are still dominant among $41.4 \%$ of people who work in the agricultural sector, and productivity of labor in food agricultural sub-sector is less than IDR 2.6 million/labor/ year [6]. 
TABLE I

Total Area of Rice FiEld AND its Growth in the StUdy AREA Within Period of The year 2009 TO 2014

\begin{tabular}{|c|c|c|c|c|c|c|c|c|}
\hline \multirow{3}{*}{ Year } & \multicolumn{4}{|c|}{ Municipality } & \multicolumn{3}{c|}{ District } \\
\cline { 2 - 9 } & \multicolumn{2}{|c|}{ Padang } & \multicolumn{2}{c|}{ Pariaman } & \multicolumn{2}{c|}{ Tanah Datar } & \multicolumn{2}{c|}{ Limapuluh Kota } \\
\cline { 2 - 9 } & Total Land (Ha) & Growth (\%) & Total Land (Ha) & Growth (\%) & Total Land (Ha) & Growth (\%) & \multirow{2}{*}{ Total Land (Ha) } & Growth (\%) \\
\hline 2009 & 6,684 & - & 2,833 & - & 22,904 & - & 22,222 & - \\
\hline 2010 & 7,060 & 5.63 & 2,818 & $(0.53)$ & 22,904 & 0.0 & 22,217 & $(0.02)$ \\
\hline 2011 & 6,627 & $(6.13)$ & 2,818 & 0.00 & 22,904 & 0.0 & 22,214 & $(0.01)$ \\
\hline 2012 & 6,587 & $(0.60)$ & 2,537 & $(9.97)$ & 22,945 & 0.2 & 22,203 & $(0.05)$ \\
\hline 2013 & 6,574 & $(0.20)$ & 2,523 & $(0.55)$ & 22,945 & 0.0 & 22,203 & 0.00 \\
\hline 2014 & 6,570 & $(0.06)$ & 2,523 & 0.00 & 22,945 & 0.0 & 23,709 & 6.78 \\
\hline
\end{tabular}

Looking at this unsatisfied figure, it is reasonable that agricultural land increasingly has been converted to be nonfood or non-agricultural land. Rice-field conversion has become a serious threat to food security since it progressively impacts on the loss of crops and rice production, caused by some reasons such as lower productivity of rice-field, low quality of land, and higher economic values of the land that belonged to the competitors [7]. In the other hand, population growth increased which was about $1.4 \%$ /year in the year of 2000 become $1.49 \%$ /year in 2010. It implies the demand for food will increasingly grow.

To prevent these conditions not to be worst, the government has launched the policy to protect land for food agricultural use since 2009. The regulation announces that every administrative regional level should define sustainable food agriculture land zonation and then included in plans for development. It attempts to attain and sustain selfsufficiency and food security to be continuous. Desk study analysis revealed that regulations at the national level have been launched to support the Act, but it needs meaningful and intense analysis in the aspect of technical, social and economical corresponding to district and municipality potential. This steps not established yet in the study areas.

Indonesian Act No. 25, 2004 on National Development Planning Systems has mentioned approaches to enhance coordination and harmonization among stakeholders; to ensure integration, synchronization, and synergy among center and regional development programs as well as shortterm and longer-term planning processes; to confirm consistency among planning, budgeting, implementation, and enforcement systems; to involve community participation in development; and to assure effectiveness, equality, and sustainability of using resources for development [8]. But, educating land use planners and decision-makers about sustainable agriculture is an important priority.

Besides, to realize sustainable food agriculture development there is also a must to integrate development planning between agricultural sector with non-agricultural sector through regional planning [9]. Infrastructures to support agriculture development are served by public works and transportation which require also land use planning. So, land protection for agriculture correspondingly reinforced by National Government Regulation number 12, 2012 that deal with incentive and disincentive to rule land conversion from agriculture use to non-agriculture use.

\section{Fact Findings on Settlement within the Agricultural Land in the Study Area: Mapping Analysis}

Based on mapping analysis using overlay map of land use plan published in the year 2012 and Citra satellite year 2016 of Padang, Pariaman, Tanah Datar and Limapuluh Kota, it showed that agricultural land in the same parts has been used for settlement area. Table 2 shows the quantity of settlement area within the agricultural land allocation. These findings tell us about losing of agricultural land that will turn into decreasing of agricultural production, landless, and then unsustainable agriculture development program. While at the same time it shows an increasing land for settlement area.

These figures indicate that Padang tends to convert the agricultural land more than Pariaman as a municipality since Padang is a capital city of West Sumatra Province. Tanah Datar and Limapuluh Kota districts experienced less agricultural land conversion in a percentage of land, but the larger number in the land quantity comparing to Padang and Pariaman.

TABLE II

Total Agricultural LAND Have BeEn CONVERTED to SETTLEMENT IN THE Study AREAS

\begin{tabular}{|c|c|c|c|c|}
\hline Municipality / District & $\begin{array}{l}\text { Total Agricultural } \\
\text { Land (Ha)* }\end{array}$ & $\begin{array}{l}\text { Total agricultural } \\
\text { land }(\mathrm{Ha})^{* *}\end{array}$ & $\begin{array}{l}\text { Settlement area in } \\
\text { agricultural land } \\
\text { (Ha)** }\end{array}$ & $\begin{array}{l}\% \text { of settlement area } \\
\text { in agricultural land }\end{array}$ \\
\hline Padang & 3015 & 2856 & 159 & 5.27 \\
\hline Pariaman & 2057 & 2014 & 43 & 2.08 \\
\hline Tanah Datar & 60473 & 60052 & 421 & 0.70 \\
\hline Limapuluh Kota & 43356 & 430345 & 321 & 0.74 \\
\hline
\end{tabular}

* digitizing using spatial regional plan /land use plan, the year 2012

** digitizing using Citra satellite map, the year 2015 
Tanah Datar and Limapuluh Kota are directed to develop agropolitan regions which guarantee sustainable agricultural land. However, this condition must intensively be investigated to learn how and why it happens, and to arrange the strategy how to attain and maintain sustainable agriculture development.

Figs. $1 \mathrm{a}$ and $1 \mathrm{~b}$ show condition of an example in the map using Citra satellite superimposed to the land use plan where settlement area takes place within agricultural land in subdistrict in Padang municipality. Fig. 1a shows delineation of agricultural land use according to spatial (land use) plan in the year 2012, and $1 \mathrm{~b}$ shows delineation settlement area within the agricultural land using satellite image in the year 2015.

\section{Policy Implementation on Sustainable Agricultural Land in West Sumatra}

These research findings revealed that the policies on sustainable food agricultural land have not been implemented yet at the local level [10]. Although every region has its own spatial plan that newly launched in the year 2012, the land for food-agriculture has not clearly been identified. Sustainable food-agricultural land should be formally determined by provincial regulation, thus it will be assured by the district and municipality in the land use plan, which then followed by regional mid-term development plan. Using the map-overlay method, presently found that some areas which are intended to the agricultural zone have been used for housing and settlement areas [10]. This condition happens because of a low economic impact of the land use for food-agriculture compare to non-food-agriculture or nonagricultural use. However, there is no updated formal data available to show the trend of such land conversion after many years.
Some factors as the reasons behind land conversion have been revealed among others are population, economics, social and culture, and lack of law enforcement [11]. Those factors happen to West Sumatra. Fig. 2 shows the cause and effect relation of why agricultural land conversion was escalated in study areas.

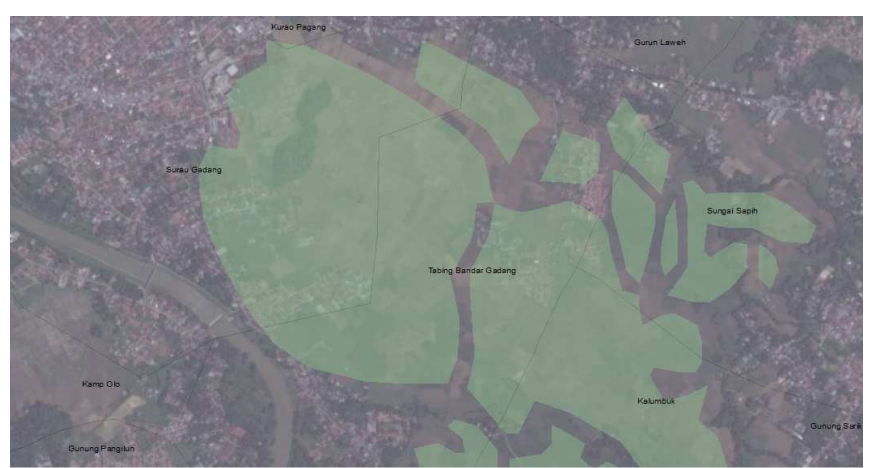

Fig. 1a Delineation of agricultural land according to spatial plan in Padang Municipality

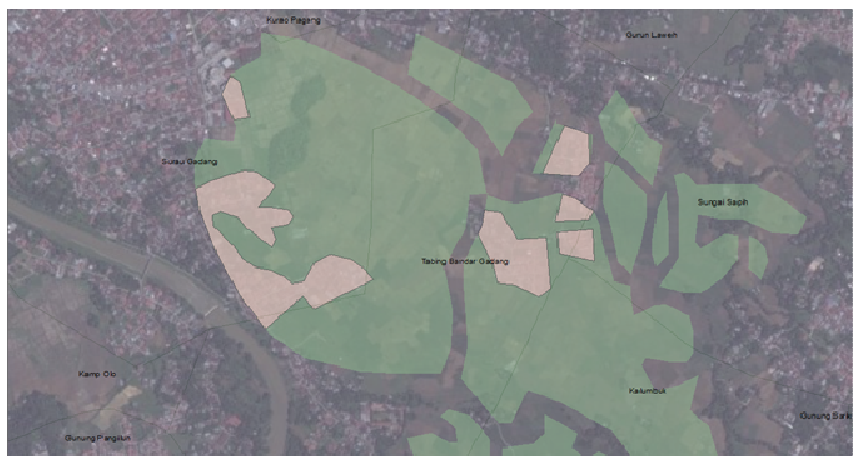

Fig. 1b Delineation of settlement area taken place within the agricultura land in Padang Municipality

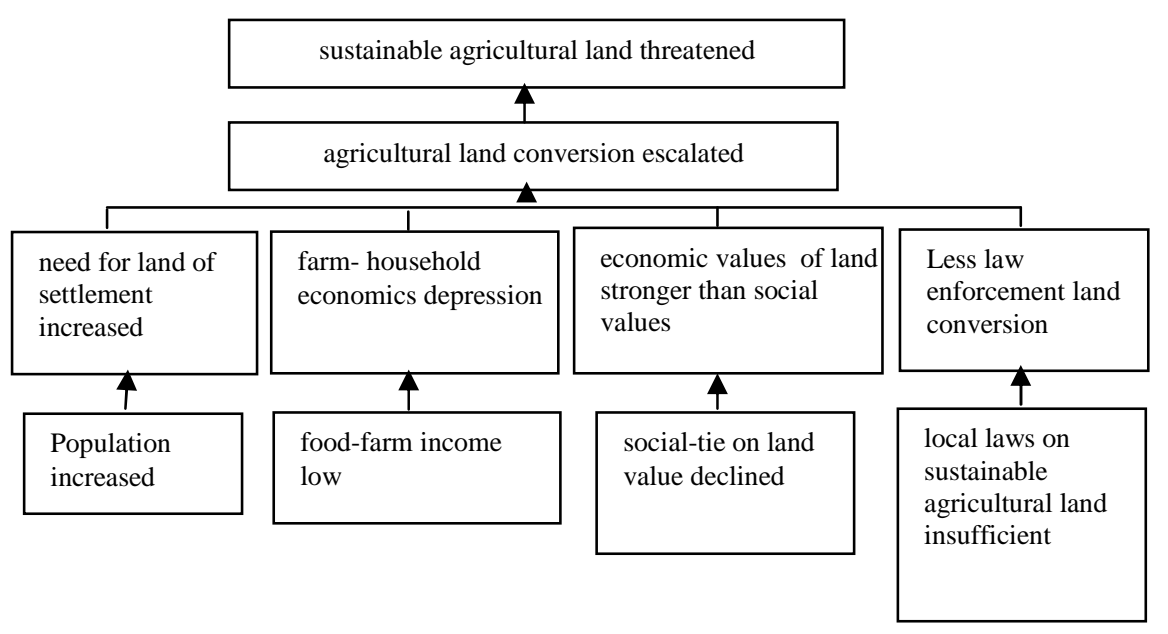

Fig. 2 The problems caused agricultural land conversion in West Sumatra

The increase in population leads to increasing the need for land for settlement. The low price of a main-food crop (paddy) will effect to low-income of farm household, which in turn relates to low motivation to continue farming activities. Besides, social bond in land value is declining because of economic land value is become stronger than its social value. So, it's now simple to replace the land-holding status from agrarians to commerce. In essence, if the local law existed to maintain land ownership, it would be able to prevent land use change. Local non-government organization in West Sumatra Province namely KAN should be involved in land use and development planning. It is a fact that KAN as a local wisdom knows and understand the local problems [12], [13] more than the national or provincial government. 
Two main factors that evolve in rapidness of agricultural land conversion are the accessibility to commercial activities and high land price. Regarding these results which may continuously happen, it will impact on agricultural landless in the long-term development. So, the land regulation and planning concerning the protection of sustainable land for food agriculture is very important, since the land is considered as input in food production system. But, at the same time, the land is also a reflection of how food production process has been done that can be measured with land productivity. This implies that land must be clearly defined as agricultural land zoning and put as a structural solution to meet the issue of food availability [14].

Food is a fundamental human right and is in endangered since the increase of agricultural land loss continuous because it will lead to food insecurity. The economic value of land for food agricultural use seems to be lower appreciated than non-food or non-agricultural use as the competitors on housing, settlement, or other built-land purposes [7]. From the regional planning perspective, agricultural land zoning is the predominant solution to solve the status of the unsustained food agricultural land.

Indonesian regulation stated that regional development planning system must refer land use plan to attain a consistency in the use of land [15]. Concerning of agricultural development to be continuous, land as the main production factors so need to have assured zonation so development programs and activities can follow. Otherwise, agricultural organizations may be upset and agriculture development will not be implemented sustainably, thus the output of agricultural land development cannot also be guaranteed. When land as an input shows its good functioning then the land will be more valued, so the agricultural land will be continuous.

Fig. 3 shows the relation of land as input and output to convince sustainable agriculture development. It shows that land in agriculture development means an important factor of production which is unique since cannot be substituted. Therefore, land availability in terms of quality and quantity for agricultural use is compulsory to achieve sustainable agriculture, food-sufficiency in specific and food-security in global.

In the other point of view, the land also takes a role of philosophical intentions as a central indicator to show development achievement for the people, because of its economic and social values. Land for agricultural use also has a strategic function to a number of people which rely on agriculture for life.

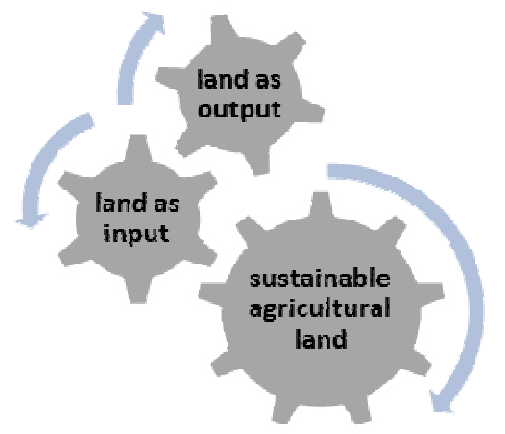

Fig. 3 Relation of land as input and output in sustainable land for agriculture development
But, as natural resources, the land is now becoming scarce because of the competition of non-agricultural use. Existing national and local government policies on food-agricultural land preservation are facing uncertain in its implementations. New policies are needed to promote a healthy environment, economic growth, and social equity simultaneously. For instance, commodity and price support programs could be restructured to allow farmers to realize the full benefits of the productivity gains made possible through alternative practices. Credit system could be modified to encourage a decentralization in small family farms. Government and university grant research policies could be modified to emphasize the development of sustainable alternatives. Marketing orders and standards could also be amended to encourage increased organic farm inputs to use. For those reasons, integration of local, regional, and national policy concerns must be created to address sustainable agricultural land.

\section{E. The Assessment on Land Policy Implementation}

The assessment of policy implementation on sustainable land for agriculture in West Sumatra found that there is a lack of local regulation and still limited efforts to prevent land conversion in districts and municipalities. Indonesian act number 41, 2009 stated that government is responsible for land and water conservation as follows: 1) protection of land and water resources; 2) maintaining of land and water resources; 3) managing of land and water resources; 4) protection from pollution. These regulations are to encourage people to maintain their agricultural or food land and to continue its utilization.

Even though Limapuluh Kota and Tanah Datar in 2015, just initiated an investigation for land food-agricultural policy, but accurate and upgrading data were found very limited. While the validity of existing land use is the key to implementing the policy. In facts, rice lands in some areas have been changed to be idle land because of lack of water resources or irrigation facilities [16]. At presents, in Limapuluh Kota, there is a program of new rice field development which about 175 hectares located in SubDistricts namely Bukit Barisan, Pangkalan, Mungka, and Harau. The final report on the delineation of sustainable agricultural land and new rice land development in Payakumbuh have not been completed. Tanah Datar has examined land for agricultural use in Sungai Tarab and Sungayang Sub-Districts. The result will be used to support regulation on agricultural land protection.

Besides, local rules on land ownership are also important to be put into consideration to ensure delineation of sustainable agricultural land, specifically the economic, social and cultural values on land. Traditionally land belongs to communal assets so that they can use the land as what they want to. So far, there is a lack of communication and coordination between the policy makers and the farmers who own, use and sell the land. The interaction and collaboration between different sectors which involved in land use policy and implementation become less. Data and information from stakeholders at national, regional and district level are essential to the zoning process in order to ensure sustainable development, including food and non-food agricultural or non-agricultural sectors. Coordination between two or more 
sectors, such as food production sector and the building sector is particularly vital for on-going food self-sufficiency and security.

Protection for sustainable food-agricultural land use should have been described since land use planning process. The government should give compensations to the community who maintain their agricultural land, according to their self-governing rules. Theoretically, it should be decided independently by local administrative level, but practically the implementation mechanism has neither been developed. The evidence of change in land use happens continuously without detail document. It then results in unceasing land conversion.

Land resource in regional development planning is very important since its identic with the regional performance itself. Indonesian Act 26, 2007 on land use planning stated that region is a unity of administrative and functional region. Land in development planning has a meaning of space as well as the place that have to be well managed in order to perform development. In this case, land plays an important role in development as an input of development but at the same time, the land also plays an output where the achievement of development can be measured, envisioned, and believed.

\section{CONCLUSIONS}

This research revealed that agriculture development plan and housing or settlement development plan in the district and municipalities have paid no attention to the land use plan on sustainable food agriculture in specific and regional land use plan in general. The land is essential to reach and maintain food security at national or provincial level. The national government has put into regulation that agricultural land has to be sustained; in turn, it should be identified by provincial level. When there is no land as input, will be no agricultural output available. This national regulation has not been followed by technical regulation in the study area.

The efforts to classify and protect sustainable foodagricultural land should be started from the local administrative region wherein land ownerships have its place. Regional development planning should be consistent with the area allocated by spatial (land use) planning so that foodagriculture development must be indicated within Regional Land Use Plan and Detail Land Use Plan Document. Midterm and short-term regional development planning should define the agricultural zoning.

Sustainable land for agriculture needs support from local, district or municipality to attain. Integrated and participatory planning vertically and horizontally would be a solution to fill the missing data on agricultural land conversion and low enforcement might be taken in place.

\section{ACKNOWLEDGMENT}

The authors delivered our thanks to Rector of Andalas University for Research grant in 2016 under contract No. 52/ UN.16/HKRGB/LPPM/ 2016.

\section{REFERENCES}

[1] The Republic of Indonesia. 2009. Act number 41, 2009 on Food Agricultural Sustainable Land.

[2] Manelli, Alberto. 2016. New Paradigms For A Sustainable WellBeing. Agriculture and Agricultural Science Procedia. Vol. 8. p. 617627. Elsevier

[3] Sara, Fabbrizzia., Magginob, Filomena., Marinellic, Nicola., Menghinic, Silvio., and Riccia, Cecilia., and Sacchellic, Sandro . 2016. Sustainability and Food: a Text Analysis of the Scientific Literature. Agriculture and Agricultural Science Procedia. Vol. 8. p. 670-679. Elsevier

[4] Merriam, S. B. (2002): Qualitative Research in Practice: Examples for Discussion and Analysis. Jossey-Bass. A Wiley Company.

[5] BPS, 2009-2015 Statistics of West Sumatra. Padang. Indonesia

[6] Ministry of National Development Planning. 2013. Studi Pendahuluan Rencana Pembangunan Jangka Menengah Nasional (RPJMN) Bidang Pangan dan Pertanian 2015-2019. Background Study: Midterm National Development Plan on Food and Agriculture, 2015-2019. Directorate Food and Agriculture.

[7] Nurliani and Rosada, Ida. 2016. Rice-Field Conversion and Its Impact on Food Availability. Agriculture and Agricultural Science Procedia. Vol. 9. p. 40-46. Elsevier

[8] Indonesian Government. (2004). Indonesian Act number.25, 2004 on National Development Planning Systems.

[9] Noer, Melinda. 2016. Bridging Food Security and Sustainable Agriculture Development through Regional Planning. IJASEIT Vol.6 (2016) No. 3. ISSN: 2088-5334. http://ijaseit.insightsociety.org

[10] Noer, Melinda., Yossyafra., Hakimi, Rini., Reza, Muhamad. 2016 The Study on Land Use Competition for Agriculture and Settlement in West Sumatra Province. Research Grants - Andalas University.

[11] Hernagustiana, E. 2012. Studi on Land Agricultural Conversion to Non-agriculture: Land Conversion in By-pass Road Koto Tangah, Padang. Thesis-unpublished. Andalas University.

[12] Noer, Melinda. 2014. Local Institutional Based in Regional Development for Food Security. Seminar Proceeding on Sustainable Integrated Agricultural Development for Food Security in Asia Era. University of Sebelas Maret. ISBN. 978-602-14235-4-7. p. 430-438.

[13] Haris, Zainal.A., Agustar A., Noer, Melinda,, Yulnafatmawita. 2015. Implementation of Corporate Social Responsibility (CSR) of Cement Factory: Partnership Program, Environmental Guidance, and National Company-Care. IJASEIT Vol. 5(2015) No.6. ISSN: 20885334. http://ijaseit.insightsociety.org

[14] Longo, Patrizia. 2016. Food Justice and Sustainability: a New Revolution. Agriculture and Agricultural Science Procedia. Vol. 8. P. 31-36. Elsevier

[15] The Republic of Indonesia. 2004. Act number 25, 2004 on National Development Planning System.

[16] Department of Agriculture, Plantations, and Forestry-Tanah Datar District. 2015. Final report on Sustainable Food-Agricultural Land of Tanah Datar District. 